\title{
Federal Powers to Control Communicable Conditions: Call for Reforms to Assure National Preparedness and Promote Global Security
}

\author{
James G. Hodge, Jr., Lawrence O. Gostin, Wendy E. Parmet, Jennifer B. Nuzzo, and Alexandra Phelan
}

Keywords: Quarantine, Legal aspects, Communicable disease

$\mathrm{D}$ ESPITE INCREASING AND SIGNIFICANT GLOBAL RISKS from emerging infectious diseases (eg, SARS in 2003, H1N1 in 2009, MERS and Ebola in 2014), federal powers to conduct accurate surveillance and nontherapeutic countermeasures are antiquated and, at times, ineffectual. After several prior attempts to modernize its rules over the past decade, ${ }^{1}$ the US Centers for Disease Control and Prevention (CDC) issued a notice of proposed rulemaking $(\mathrm{NPRM})^{2}$ on August 15, 2016, to modernize its powers to control communicable diseases pursuant to the Public Health Service Act (PHSA). ${ }^{3}$ Through October 14, CDC has received more than 15,000 public comments on its NPRM.

Intended largely for emergencies, CDC's proposed regulations specify its authority to assess, test, examine, apprehend, isolate, quarantine, and monitor individuals with potentially infectious conditions arriving to or traveling within the United States. CDC is reportedly expediting the process for a final regulation before the end of President Obama's administration.
Modernizing federal powers could strengthen disease preparedness in the United States and globally. Still, the proposed regulations must respect constitutional rights while being effective and evidence-based. We examine major legal, ethical, and policy aspects of the proposed regulations that will require revision to be fair and effective.

\section{Proposed Federal Communicable Disease Control Powers}

CDC proposes to transform antiquated standards into modern, flexible powers. Pursuant to the PHSA, ${ }^{4} \mathrm{CDC}$ is authorized to detain, medically examine, and release persons who (1) are traveling into the United States or between states and (2) are suspected of carrying a communicable disease (limited via Executive $\operatorname{Order}^{5}$ to conditions like plague, smallpox, and Ebola). ${ }^{6}$

CDC has repeatedly sought to amend federal disease control regulations. In 2005, it issued comprehensive

James G. Hodge, Jr., JD, LLM, is Professor of Public Health Law and Ethics; Director, Public Health Law and Policy Program; and Director, Network for Public Health Law - Western Region Office, Sandra Day O'Connor College of Law, Arizona State University, Phoenix, AZ. Lawrence O. Gostin, JD, is University Professor and Faculty Director, O'Neill Institute for National and Global Health Law, Georgetown University, Washington, DC; and Director, World Health Organization Collaborating Center of Public Health Law and Human Rights. Wendy E. Parmet, JD, is Matthews University Distinguished Professor of Law; Professor of Public Policy \& Urban Affairs; and Director of the Center for Health Policy \& Law, Northeastern University, Boston, Massachusetts. Jennifer B. Nuzzo, DrPH, SM, is Senior Associate, UPMC Center for Health Security, and Associate, Department of Epidemiology, Johns Hopkins Bloomberg School of Public Health, Baltimore, Maryland. Alexandra Phelan, LLM, is an Adjunct Professor in Public Health Law and Ethics, and a doctoral candidate, Georgetown University Law Center, Washington, DC. 
regulations to allow individuals to be detained up to 3 business days pending an order for quarantine, isolation, conditional release, or a "finding of no infection." 7 Facing major objections, these draft regulations were subsequently shelved. In 2012, CDC slightly amended its existing regulations to broaden their scope and revamp definitions of quarantine, isolation, and other existing terms. ${ }^{8}$

According to the NPRM, CDC now seeks to clarify its powers during "public health emergencies," loosely defined to include any "communicable disease event" that could "spread" or cause "death or serious illness if not properly controlled." Its proposed regulations lay out upgraded prevention measures at US airports and other transit locations where individuals engage in international, interstate, or even purely intrastate travel. ${ }^{10,11}$ Measures include active screening techniques such as observation, questioning, and review of travelers' documents and health records. ${ }^{12}$

$\mathrm{CDC}$ also proposes to extend its powers to anyone "reasonably believed" to have a "quarantinable communicable disease" (not just specified conditions) to enable early response to emerging threats. 13 "Ill" persons include anyone with signs (eg, fever, rash, headache, persistent cough) or "any other symptoms or indications" determined by federal agents. ${ }^{14}$ As in 2005 , the newly proposed regulations authorize the limited apprehension, and subsequent quarantine or isolation (up to 72 hours), of suspected ill individuals pending a medical review. ${ }^{15}$ Affected persons may be asked to agree to CDC's terms as a condition of their isolation, quarantine, release, examination, hospitalization, vaccination, or treatment. ${ }^{16}$

\section{Foundational Reforms}

The United States is one of 196 states parties to the World Health Organization's (WHO) International Health Regulations (IHR). ${ }^{17}$ IHR require preparedness and response to potential public health emergencies of international concern (PHEIC) while avoiding "unnecessary interference with international travel and trade." ${ }^{18}$ Countries must (1) implement minimum public health standards and capacities for detecting infectious diseases, (2) notify WHO of events that may constitute a PHEIC, and (3) initiate effective responses to public health risks. ${ }^{19}$

To effectuate these mandates, it is essential that public health laws in the United States and all WHO IHR member states respect persons' dignity, human rights, and fundamental freedoms, ${ }^{20}$ including "gender, sociocultural, ethnic or religious concerns." 21 To impose measures such as quarantine, isolation, vaccination, or medical treatment, countries must clearly identify the risks, ${ }^{22}$ use the least restrictive measures available, ${ }^{23}$ and respond appropriately, ${ }^{24}$ transparently, and without discrimination. ${ }^{25}$

CDC's proposed regulations expressly seek to facilitate IHR implementation nationally. The United States has also funded and led the Global Health Security Agenda. ${ }^{26}$
Consequently, CDC's regulations carry significant normative weight as a potential model for other countries. However, as discussed below, the regulations potentially conflict with many IHR obligations, including transparency, due process, and respect for fundamental freedoms.

\section{FEDERALISM}

Since the Constitution's founding, states and localities have had primary responsibility for protecting public health through their "police powers." The PHSA 27 authorizes the Surgeon General (later transferred to CDC) to impose quarantines to prevent the spread of disease across state lines, but this power has been used sparingly. CDC has issued only one domestic quarantine order in the past 50 years (ie, the well-publicized 2007 case of Andrew Speaker, who was infected with multidrug-resistant tuberculosis).

CDC advises and supports state, territorial, tribal, and local responses to outbreaks, but it lacks sufficient personnel to institute and implement quarantines, isolation, or other social distancing measures nationally. Consequently, it relies on subnational officials who are more likely to be aware of conditions in their own communities. Many states have more fully developed legal safeguards guiding implementation of social distancing powers than under federal law. As well, it can be easier and less expensive to seek review in state (versus federal) courts.

CDC's proposed regulations should codify its traditional secondary role, limiting federal apprehension, quarantine, or isolation orders to situations where (1) states have requested assistance or (2) CDC is aware that state or local governments are unable or unwilling to act appropriately. Even in such cases, CDC should consult and coordinate with state and local authorities whenever feasible.

\section{EFFICACY}

During recent outbreaks, CDC used its point-of-entry powers to monitor temperatures of incoming travelers from certain countries or regions, question them, review their travel documents, and prevent potentially exposed individuals from using mass transit. ${ }^{28}$ These exercises have limited utility. During the Ebola outbreak, CDC identified more than 30,000 travelers who were monitored for 21 days because of their potential exposure. Many were barred from returning to work, traveling long distances, or visiting public spaces. ${ }^{29}$ In the end, no monitored traveler was actually infected with Ebola.

Public acceptance and compliance with such measures tend to correlate with their effectiveness and perceptions of value. Societal loss of confidence in public health measures undermines their effectiveness, eroding overall preparedness and response. For these reasons, CDC must ensure its communicable disease powers are efficacious, minimally 
restrictive, and publicly acceptable. Quarantine, isolation, travel restrictions, and traveler screening and monitoring should only be done when (1) there is reasonable evidence that they are effective at reducing transmission, (2) they infringe minimally on individual rights while maintaining efficacy, and (3) failure to use them significantly increases risks to the public's health. ${ }^{30}$

\section{Procedural Due Process}

The Fifth Amendment prohibits the federal government from depriving individuals of liberty "without due process of law." In cases of civil confinement, including isolation and quarantine, government must provide adequate notice and prove to a neutral decision maker by clear and convincing evidence that the detention is the least restrictive alternative. ${ }^{31}$ Due process also demands that government pay for counsel when individuals cannot afford representation. ${ }^{32}$

CDC's proposed regulations fall well short of these constitutional standards. They would permit the agency to apprehend individuals without setting any time limit before any process is afforded. Reassessment and medical review procedures are conducted by CDC agents instead of before a neutral decision maker. Affected individuals do not have to be released from quarantine or isolation even if less restrictive alternatives are available. Although CDC is willing to pay for a medical review for individuals who cannot afford it, the proposed regulations do not assure appointment of counsel for individuals unable to afford a lawyer.

CDC should require notice and a hearing before a neutral decision maker prior to the issuance of a quarantine or isolation order, or in exigent circumstances, in close proximity of detention. This hearing should combine the reassessment and medical review processes. Individuals should also have the right to seek repeated review and reassessment every 30 days during their detention. ${ }^{33}$ The proposed regulations only suggest the rescission of a federal order based on significant new or altered facts or medical evidence. $^{34}$

At any hearing, CDC should have to prove that quarantine or isolation is the least restrictive option available. Presently, it need only "consider" whether "less restrictive alternatives" entered into the record ${ }^{35}$ would "adequately serve to protect the public health." 36 Individuals who cannot afford counsel should be provided one. Further, CDC should clarify that its review process is not an exclusive remedy. Individuals must be able to seek judicial review via a petition for habeas corpus without exhausting internal CDC procedures.

\section{Medical Examination, Treatment, AND INTERVENTIONS}

CDC's proposed powers to require medical examinations, vaccinations, and treatments ${ }^{37}$ without specific, informed consent raise significant legal and ethical concerns. Informed consent is an important ethical value that can be overridden only to avert a significant risk to self or others. Mere suspicions that an individual poses a significant risk is an insufficient basis to impose mandatory examinations or treatments without informed consent.

CDC seeks to require individuals to agree to terms set solely by the agency as a condition of their examinations or treatment. On first glance, these agreements may plausibly reflect principles of informed consent. However, CDC's proposed regulations clarify that an "... individual's consent shall not be considered as a prerequisite to any exercise of any authority." 38 As a result, examinations, treatments, or other measures may potentially be imposed without consent. The exercise of compulsory powers cannot ethically or constitutionally rest on the mere suspicion of illness or be subject to such one-sided terms.

\section{Thoughtful Modernization}

CDC is right to modernize its powers in the face of major pandemic threats. Its proposed regulations, however, are in tension with international legal standards and domestic constitutional and ethical norms. Revising the regulations to better reflect principles of efficacy, due process, and public health ethics within a federalist system will buttress national preparedness and provide a substantive model for other countries and international institutions.

\section{ACKNOWLEDGMENT}

The authors would like to acknowledge the following individuals for their contributions, research, and assistance in the production of this manuscript: Sarah Wetter, JD candidate (2017), Sandra Day O'Connor College of Law, ASU; and Sarah Noe, BA candidate (2017), ASU. We also acknowledge Scott Burris, JD, at Temple University Beasley School of Law, and Amy Kapczynski, MPhil, MA, JD, and her students at Yale Global Health Justice Partnership for their contributions to initial ideas for the manuscript.

\section{REFERENCES}

1. Gostin LO. A very long journey: a decade's quest for quarantine regulations. Milbank Q 2016;94(4):724-728.

2. Control of Communicable Diseases, 81 Fed. Reg. 157 (proposed August 15, 2016).

3. Public Health Service Act, 42 U.S.C. $\S$ 6A (2016).

4. Public Health Service Act, 42 U.S.C. $\S 6$ 6 (2016).

5. Exec. Order No. 13,295, 68 Fed. Reg. 68 (April 9, 2003).

6. 42 C.F.R $\S \S 70-71$ (2007).

7. Control of Communicable Diseases, 70 Fed. Reg. 229 (proposed November 30, 2005). 
8. Control of Communicable Diseases: Interstate; Scope and Definitions, 77 Fed. Reg. 247 (proposed December 26, 2012).

9. Control of Communicable Diseases, 81 Fed. Reg. 157, § 70.1 (proposed August 15, 2016).

10. Control of Communicable Diseases, 81 Fed. Reg. 157, $\S 70.10$ (proposed August 15, 2016).

11. Control of Communicable Diseases, 81 Fed. Reg. 157, $\S 70.5$ (proposed August 15, 2016).

12. Control of Communicable Diseases, 81 Fed. Reg. 157, $\S 70.1$ (proposed August 15, 2016).

13. Control of Communicable Diseases, 81 Fed. Reg. 157, § 70.1 (proposed August 15, 2016).

14. Control of Communicable Diseases, 81 Fed. Reg. 157, § 70.1 (proposed August 15, 2016).

15. Control of Communicable Diseases, 81 Fed. Reg. 157, § 70.1 (proposed August 15, 2016).

16. Control of Communicable Diseases, 81 Fed. Reg. 157, § 70.1 (proposed August 15, 2016).

17. IHR, Article 59; Constitution of the World Health Organization, Arts 21(a) and 22.

18. IHR, Article 2.

19. IHR, Articles 5, 6, and 13.

20. IHR, Article 3.1.

21. IHR, Article 32.

22. IHR, Articles 23.2, 31.1, 31.2, and 43.1.

23. IHR, Articles 23.2, 31.2, and 43.1.

24. IHR, Articles 23.2, 23.5, 30, 31.2, and 43.2.

25. IHR, Article 42.

26. Exec. Order No. 13,747, 81 Fed. Reg. 78701 (Nov. 4, 2016).

27. Public Health Service Act, 42 U.S.C. § 6A (2016).

28. Gostin LO, Hodge JG Jr, Burris S. Is the United States prepared for Ebola? JAMA 2014;312(23):2497-2498.

29. Stehling-Ariza T, Fisher E, Vagi S, et al. Monitoring of persons with risk for exposure to Ebola virus diseaseUnited States, November 3, 2014-March 8, 2015. MMWR Morb Mortal Wkly Rep 2015;64(25):685-689.
30. Parmet WE. Legal power and legal rights-isolation and quarantine in the case of drug-resistant tuberculosis. $N$ Engl J Med 2007;357(5):433-435.

31. Vitek v. Jones, 463 U.S. 480 (1979) (requiring the state prove by "clear and convincing evidence" that an individual is ill and dangerous in cases of civil commitment for mental illness); Covington v. Harris, 463 F.2d 617, 624 (D.C. Cir. 1969) (state must show commitment to a mental hospital is the "least restrictive alternative"); Greene v. Edwards, 263 S.E. 2d 661 (W. Va. 1980) (holding that the due process protections required in cases of civil commitment for mental illness, including right to appointment of counsel should apply to quarantines).

32. Foucha v. Louisiana, 504 U.S. 71, 72 (1992).

33. Foucha v. Louisiana, 504 U.S. 71, 77 (1992) (individual cannot be kept in civil commitment if the state can no longer show that the original grounds for commitment continue).

34. Control of Communicable Diseases, 81 Fed. Reg. 157, § 70.16(m) (proposed August 15, 2016).

35. Control of Communicable Diseases, 81 Fed. Reg. 157, $\S 70.16(\mathrm{j})$ (proposed August 15, 2016).

36. Control of Communicable Diseases, 81 Fed. Reg. 157, $\S$ 70.15(c) (proposed August 15, 2016).

37. Control of Communicable Diseases, 81 Fed. Reg. 157, § 70.2 (proposed August 15, 2016).

38. Control of Communicable Diseases, 81 Fed. Reg. 157, $\S \S$ 70.18, 71.40 (proposed August 15, 2016).

Address correspondence to: James G. Hodge, Jr., JD, LLM Sandra Day O'Connor College of Law 111 E. Taylor St. MC 9520 Phoenix, AZ 85004-4467

E-mail: james.hodge.1@asu.edu 